\title{
Molecular Cloning and Isolation of a Cyanobacterial Gene Which Increases the UV and Methyl Methanesulphonate Survival of $\operatorname{rec} A$ Strains of Escherichia coli K12
}

\author{
By CIARAN M. GEOGHEGAN ${ }^{1 *}$ AND JAMES A. HOUGHTON ${ }^{2}$ \\ 'Department of Bacteriology, Agricultural Institute, Moorepark, Co. Cork, Ireland \\ ${ }^{2}$ Department of Microbiology, University College, Galway, Ireland
}

(Received 8 April 1986; revised 21 August 1986)

\begin{abstract}
The unicellular cyanobacterium Gloeocapsa alpicola contains both photoreactivation and excision repair mechanisms for correcting UV-induced damage to its cellular DNA. An $11.5 \mathrm{~kb}$ EcoRI fragment was isolated from a cosmid bank of $G$. alpicola and was shown to complement a rec $A$ deletion in Escherichia coli $\mathrm{S} .17$ and $\mathrm{JC10289}$. These $r e c A$ strains showed increased survival to UV and methyl methanesulphonate (MMS) when transformed with the cyanobacterial DNA fragment, and also showed filamentation in response to UV irradiation. Preliminary analysis of the protein encoded by the cyanobacterial DNA fragment indicated a major protein of 39000 $\mathrm{Da}$; this is very similar in size to the recA protein of $E$. coli.
\end{abstract}

\section{INTRODUCTION}

Cyanobacterial DNA repair systems have been poorly studied in the past. Kumar (1963) demonstrated that Anacystis nidulans responded to UV light in a similar manner to other organisms. The existence of enzymic photoreactivation was demonstrated in Plectonema boryanum by Werbin \& Rupert (1968). A photoreactivating enzyme was purified from Anacystis nidulans by Saito \& Werbin (1970) and shown to cleave pyrimidine dimers in vitro (Saito \& Werbin, 1970) and in vivo (Tang \& Asato, 1978). The efficiency of the photoreactivating system of Gloeocapsa alpicola was demonstrated by Williams et al. (1979), who showed that 60 min exposure to blue light restored the viability of UV-irradiated cells to pre-irradiation levels. A dark repair system for pyrimidine dimer removal has also been demonstrated in G. alpicola (O'Brien \& Houghton, 1982a). Pyrimidine dimers were induced in a fluence-dependent manner and chromatographic analysis of labelled DNA extracted from cells grown in nonphotoreactivating conditions showed that the dimers had been removed by an excision repair system. This DNA degradation was inhibited by caffeine and acriflavine (O'Brien \& Houghton, $1982 b$ ), further confirming the existence of a dark excision repair system. O'Brien \& Houghton $(1982 b)$ also reported that cyanobacteria may have a damage-inducible repair function. Cultures of Synechocystis PCC 6308 (G. alpicola) were exposed to a sublethal UV dose $\left(19 \cdot 2 \mathrm{~J} \mathrm{~m}^{-2}\right)$ and incubated for $24 \mathrm{~h}$ under non-photoreactivating conditions. Half of each culture was then exposed to a challenge UV dose $\left(198 \mathrm{~J} \mathrm{~m}^{-2}\right)$ and the other half untreated. During a $48 \mathrm{~h}$ period after the challenge dose, there was a $40 \%$ loss of radioactivity from DNA in the induced culture, compared to a $60 \%$ loss in the absence of induction. In Escherichia coli, this limitation of DNA degradation is mediated by the rec $A$ protein (Marsden et al., 1974). Satta et al. (1979) have also shown that synthesis of recA protein is necessary for limitation of DNA degradation. The damage-inducible repair function observed in G. alpicola may be similar to the SOS system of $E$. coli, since both the limitation of DNA degradation and its removal by inhibition of protein

Abbreviation: MMS, methyl methanesulphonate. 
synthesis have been demonstrated by O'Brien \& Houghton (1982b). The aim of this study was to clone and identify a gene from $G$. alpicola which may be involved in inducible DNA repair. The approach was to isolate a cyanobacterial gene similar to the rec $A$ gene of $E$. coli and study its effects on a variety of $E$. coli mutants. $E$. coli was chosen as a host since a complete range of mutants is available to study the pleiotropic effects of the $\operatorname{rec} A$ gene, whereas no such mutants are available in $G$. alpicola.

\section{METHODS}

Organisms. Gloeocapsa alpicola 1430/1 (Lyngbye) Bornet was obtained from the Culture Centre of Algae and Protozoa, Cambridge, UK [Rippka et al. (1979) reclassified G. alpicola as Synechocystis]. Escherichia coli S.17, which has a deletion in its rec $A$ gene (Simon et al., 1983), was obtained from the University of Bielefeld, FRG. $E$. coli strains AB1157 (a wild-type strain for repair functions) and JC10289 (a recA-deleted strain) were obtained from the E. coli Genetic Stock Center, Yale University, New Haven, USA. E. coli strains BHB 2688 and BHB 2690 (Hohn, 1979) were used for the preparation of in vitro packaging mixes as described in Maniatis et al. (1982).

Growth of bacteria. Liquid cultures of G. alpicola were grown in a modified medium of Allen (1968) as described by Williams et al. (1979), incubated in an illuminated orbital incubator at $30 \pm 2{ }^{\circ} \mathrm{C}$ at $100-120$ oscillations $\mathrm{min}^{-1}$. Light $(2000 \mathrm{~lx})$ was provided by white fluorescent tubes.

E. coli was routinely grown at $37{ }^{\circ} \mathrm{C}$ on Luria broth (LB) or Luria agar $(1.5 \%$, w/v) containing the appropriate antibiotic when required.

Plasmids. pJC79 $\left(\mathrm{Ap}^{\mathrm{r}} \mathrm{Tc}^{\mathrm{r}} \mathrm{cos}\right)$ was used as a cosmid vector for the construction of the gene bank. pTM-2 $\left(\mathrm{Ap}^{r} \mathrm{rec}^{+}\right)$was used as a source of $E$. coli recA and pACYC184 $\left(\mathrm{Cm}^{\mathrm{r}} \mathrm{Tc}^{\mathrm{r}}\right)$ was used to subclone DNA from recombinant cosmids. Plasmid DNA was routinely prepared by standard E. coli cleared lysis procedures and isopycnic $\mathrm{CsCl}$ centrifugation. A rapid method for screening plasmids was also used (Birnboim \& Doly, 1979).

Lysis of G. alpicola. Due to the highly resistant outer sheath and cell wall of G. alpicola (Jensen \& Sicko, 1973) standard lysing procedures were not suitable. A rigorous lysis method was developed involving EDTA treatment of the external sheath, Sarkosyl NL-35 treatment of the proteins in the outer cell layer, osmotic and temperature shock of the outer membrane, followed by lysozyme and Sarkosyl treatment of the peptidoglycan and internal membrane. The procedure was as follows. A $50 \mathrm{ml}$ volume of a late-exponential phase culture was centrifuged and

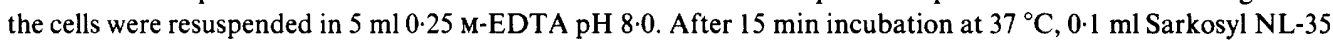
was added and mixed for $10 \mathrm{~min}$ at $37^{\circ} \mathrm{C}$. The mixture was centrifuged at $4000 \mathrm{~g}$ for $10 \mathrm{~min}$ and then the cells were resuspended in $4 \mathrm{ml} \mathrm{l} .6 \mathrm{M}$-sucrose, $50 \mathrm{~mm}$-Tris, $1 \mathrm{~mm}$-EDTA, pH 8.0, and incubated for $15 \mathrm{~min}$ at $37^{\circ} \mathrm{C}$, followed by centrifugation at $20000 \mathrm{~g}$ for $15 \mathrm{~min}$. The cells were resuspended in $4 \mathrm{ml}$ distilled water and immersed in liquid $\mathrm{N}_{2}$ for $60 \mathrm{~s}$; after thawing, $2 \mathrm{ml}$ lysozyme $\left(5 \mathrm{mg} \mathrm{m}^{-1}\right)$ was added and the mixture was incubated at room

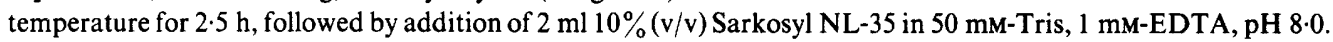
The lysate was extracted twice with phenol, and the aqueous phase was centrifuged at $20000 \mathrm{~g}$ for $20 \mathrm{~min}$. The total DNA so released was purified by standard extractions and $\mathrm{CsCl}$ isopycnic centrifugation.

Construction of cosmid bank. Target DNA was prepared by digesting total $G$. alpicola DNA with varying concentrations of Sau3A over a fixed time period. Reaction conditions using $0.5 \mathrm{U}$ Sau $3 \mathrm{~A}$ per $0.5 \mu \mathrm{g} \mathrm{DNA} \mathrm{h}{ }^{-1}$ provided the maximum number of DNA molecules in the $35-40 \mathrm{~kb}$ region. The cosmid vector pJC79 was digested to completion with BamHI and the target DNA was ligated into the tetracycline resistance gene of the vector at a molar ratio of 10:1 (target : vector). The final DNA concentration in the ligation mixture was $750 \mu \mathrm{g} \mathrm{ml}^{-1}$. After ligation, the DNA was checked on a $0.7 \%(w / v)$ agarose gel to confirm the formation of concatamers. The concatameric DNA was packaged and transfected to the recA host S.17. Positive recombinant clones were selected by insertion inactivation of the tetracycline resistance gene of pJC79. The number of recombinant clones required to represent the entire genome of G. alpicola was calculated to be 500 by the mehod of Maniatas et al. (1982).

MMS enrichment for selection of rec A-complementing ability. The cosmid bank was spotted onto 10 master plates, each containing 50 colonies. These colonies were replica plated, grown and the cells subsequently washed from the agar with $4 \mathrm{ml}$ sterile saline. Samples $(100 \mu \mathrm{l})$ from each plate were spread on MMS gradient plates, prepared by placing $100 \mu 12 \%(\mathrm{w} / \mathrm{v})$ MMS in the centre of LB-ampicillin plates and allowing it to diffuse into the medium to form a concentration gradient. The plates were incubated at $37^{\circ} \mathrm{C}$ for $48 \mathrm{~h}$. Colonies that grew near the centre of the MMS gradient plates were deemed to have a higher level of DNA repair potential than the host strain S.17/pJC79. Since these colonies had been treated with the mutagen MMS, the apparent increase in survival could have been due to an up mutation in some other gene. To disprove this, the colonies from the relevant original master plates were individually screened for increased UV survival, using a rapid UV screening test.

Selection for recA-complementing ability using UV irradiation. The colonies from the relevant master plates were analysed for an increase in their UV resistance compared to the S.17/pJC79 recA host. Each colony was resuspended in $300 \mu 10.85 \%$ sterile saline, and the cells were then streaked across an LB-ampicillin plate in one 
direction only. The plates were masked into three sections and UV irradiated $(253.7 \mathrm{~nm})$ at 0,4 and $8 \mathrm{~J} \mathrm{~m}^{-2}$ under gold light conditions $(500-700 \mathrm{~nm})$ to prevent enzymic photoreactivation of the UV damage. The cells were incubated in the dark overnight at $37^{\circ} \mathrm{C}$ and the plates examined and scored for increase in UV resistance.

Confirmation that the increased UV and MMS survival observed in E. coli $S .17$ was cosmid associated. DNA was isolated from the relevant strains and retransformed into another rec $A$-deleted strain of $E$. coli, JC10289. The transformed clones of JC10289 were analysed for increase in UV resistance by the rapid UV survival screening method.

Quantitative analysis of the complementary effect of recombinant cosmids on the UV survival of E. coli S.17. E. coli S. 17 containing putative recA-complementing cosmids was analysed quantitatively for UV survival. Overnight cultures of the strains were subcultured into $\mathrm{LB}$ with the selective antibiotic and grown to an $\mathrm{OD}_{600}$ of $0 \cdot 3-0 \cdot 4$. The cells were left in $0.85 \%$ saline for $30 \mathrm{~min}$ before irradiation to allow DNA replication to reach completion. Irradiation was done by exposing the culture (with agitation) to a mercury discharge lamp, emitting mainly at $253.7 \mathrm{~nm}$. Dose rates were measured with a UV radiometer (UV Photoproducts). All irradiations were done under gold light to prevent enzymic photoreactivation of the UV damage. After irradiation, serial dilutions were plated onto LB agar with the selective antibiotic. After overnight incubation at $37^{\circ} \mathrm{C}$ in the dark, the number of viable cells was counted and survival expressed as a percentage of the initial cell number. S.17/pJC79 was used as a negative and S.17/pTM2 as a positive control.

Quantitative analysis of the complementary effect of recombinant cosmids on the MMS survival of E. coli S.17. The response of putative recA-complementing cosmids in $\mathrm{S} .17$ was determined by plating the cells on increasing concentrations of MMS. Cultures were grown overnight in LB with the selective antibiotic. Serial dilutions were made in $0.85 \%$ saline and $100 \mu \mathrm{l}$ quantities of each dilution were spread onto LB plates containing MMS at 0,50 , 100,150 and $200 \mathrm{\mu g} \mathrm{ml}^{-1}$. The plates were incubated at $37^{\circ} \mathrm{C}$ and colonies were counted after $12-24 \mathrm{~h}$. The number of surviving cells was expressed as a percentage of the initial cell number.

Filamentation analysis of $E$. coli in response to UV irradiation. Cultures were grown overnight in LB, subcultured and grown to an $\mathrm{OD}_{600}$ of 0.5 . Cells were collected by centrifugation and resuspended in $0.85 \%$ saline, and the suspension irrradiated at $5 \mathrm{~J} \mathrm{~m}^{-2}$ under gold light conditions. The cells were collected again by centrifugation, resuspended in fresh LB medium and grown in the dark for $40-60 \mathrm{~min}$ at $37^{\circ} \mathrm{C}$. Samples were examined for filamentation by phase-contrast microscopy.

Restriction analysis of plasmid DNA. Enzyme reactions were routinely done in $30 \mu$ volumes in which a ratio of $1 \mu \mathrm{g}$ DNA to 2-3 U enzyme was used. A low-salt buffer ( $10 \mathrm{mM}$-Tris pH 7.5, $6 \mathrm{mM}-\mathrm{MgCl}_{2}, 1 \mathrm{~mm}$-DTT) or a highsalt buffer (10 mM-Tris pH 7.5, $5 \mathrm{~mm}-\mathrm{NaCl}, 6 \mathrm{mM}-\mathrm{MgCl}_{2}, 1 \mathrm{~mm}$-DTT) was used depending on the enzyme requirement. When modifications from these conditions were required, $\mathrm{NaCl}, \mathrm{KCl}$ and $\mathrm{pH}$ were adjusted according to the manufacturer's specifications. For double digestions, the enzyme requiring the lowest salt concentration was used first, and the salt and/or $\mathrm{pH}$ requirements were then changed for the second reaction. Molecular masses of DNA fragments were determined using HindIII and XhoI digestions of $\lambda$ DNA as reference standards.

Ligation of DNA. The two preparations were combined at a molar ratio of $10: 1$ (target : vector). ATP was added

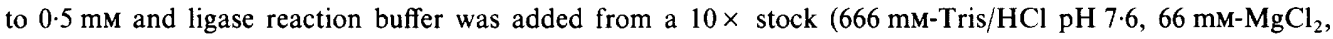
$100 \mathrm{~mm}$ DTT). One unit of T4 ligase was used and the reactions were incubated overnight at $12-14^{\circ} \mathrm{C}$.

Analysis of plasmid-encoded proteins by SDS-PAGE. Cultures $(10 \mathrm{ml})$ were grown overnight in LB with the relevant antibiotic. The cells from a $2 \mathrm{ml}$ sample of culture were collected by centrifugation, resuspended in $100 \mu \mathrm{l}$ water and $100 \mu \mathrm{l}$ PAGE loading buffer $(10 \%$, v/v, glycerol, $2 \%$, w/v , SDS, $0.0625 \mathrm{M}$-Tris $\mathrm{pH} 6.8,0.005 \%$ bromophenol blue, $5 \%, \mathrm{v} / \mathrm{v}, 2$-mercaptoethanol) and heated at $100{ }^{\circ} \mathrm{C}$ for $2 \mathrm{~min}$. Samples ( $30 \mu \mathrm{l}$ ) were loaded onto an SDS-polyacrylamide gel $(5 \%, \mathrm{w} / \mathrm{v}$, stacking, $12 \%$, w/v, separating) and the gel was run at $60 \mathrm{~V}$ for $4-5 \mathrm{~h}$. The gel was stained for $2 \mathrm{~h}$ in Coomassie staining solution, containing, per litre, $300 \mathrm{ml}$ methanol, $628 \mathrm{ml}$ water, $70 \mathrm{ml}$ acetic acid, $2 \mathrm{ml}$ Triton X-100 and $1.15 \mathrm{~g}$ Coomassie blue R250, and destained overnight with gentle agitation in methanol/acetic acid $(3: 7, \mathrm{v} / \mathrm{v})$.

\section{RESULTS AND DISCUSSION}

\section{Total DNA preparation}

Standard lysing procedures for Gram-negative bacteria were not suitable for G. alpicola. Consequently, a method was developed which facilitated the extraction and purification of DNA from this organism (see Methods). One of the problems with the purification of the DNA was the separation of the photosynthetic pigments. Despite repeated proteinase $\mathrm{K}$ treatment, phenol and phenol/chloroform extractions, the DNA was not sufficiently pure to provide a high ligation frequency in subsequent gene cloning. The inclusion of a $\mathrm{CsCl}$ purification step removed the inhibitor(s) of ligation. 


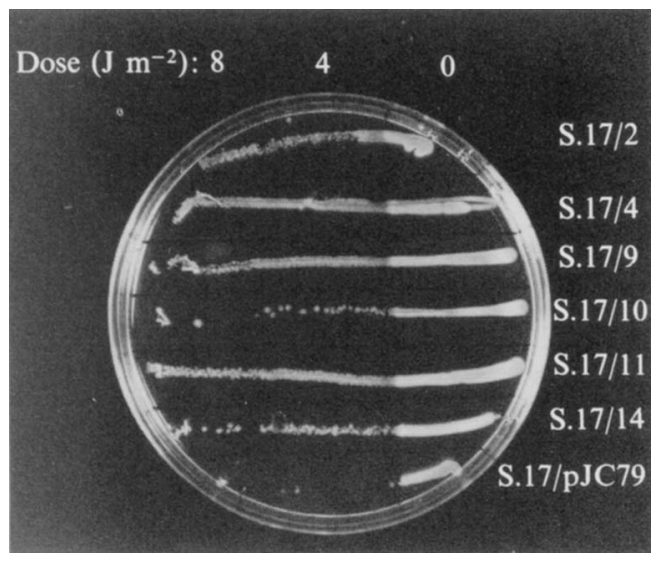

Fig. 1. UV streak test analysis on cosmia bank clones showing variation in the degree of UV resistance. The irradiation dose is shown at the top of the photograph. Clones S.17/4, S.17/9 and S.17/11 were chosen for further analysis.

\section{Selection of recA-complementing cosmid clones by MMS enrichment}

Examination of the MMS gradient plates after overnight incubation of the pooled S.17/cosmid clones revealed that growth had occurred near the centre of three of the 10 plates (the equivalent of master plates 1,4 and 5). This indicated that the cosmid bank may have contained clones which were complementing the recA mutation of the host. To ensure that the MMS selection procedure had not induced a mutation which would alter the survival of $E$. coli S.17 to the alkylating agent, the original recombinant clones from the master plates were examined for $\operatorname{rec} A$-complementing ability by UV survival analysis.

Each $E$. coli S.17/cosmid clone was individually examined for its UV survival characteristics by the rapid UV survival test. Six clones had a higher level of UV resistance than the S.17/pJC79 rec $A$ parent control strain; they varied in their degree of resistance (Fig. 1). This provided evidence for the existence of a function in the cosmid bank of G. alpicola which was capable of increasing the UV and MMS survival of the rec $A$ strain $E$. coli S.17. The three clones $(\mathrm{S} .17 / 4$, S.17/9 and S.17/11) that showed the highest level of UV resistance were chosen for further analysis. The cosmid DNA was purified from these strains and retransformed to $E$. coli JC10289. This strain has $90 \%$ of its structural $\mathrm{rec} A$ gene deleted and is consequently very sensitive to UV radiation. The cosmids purified from S.17/4, S.17/9 and S.17/11 were designated pRCG4, pRCG9 and pRCG11 respectively. UV survival analysis (data not shown) of the JC10289 derivatives demonstrated that the increased level of UV resistance which had been shown with $E$. coli S.17/4, S.17/9 and S.17/11 (Fig. 1) was also observed when pRCG4, pRCG9 and pRCG11 were present in JC10289. This directly demonstrated the association between the recA-complementing ability observed in E. coli S.17 and JC10289 and the recombinant cosmids pRCG4, pRCG9 and pRCG11.

\section{Restriction analysis of $p R C G 4, p R C G 9$ and $p R C G 11$}

The three cosmids with recA-complementing activity were analysed with a range of restriction enzymes to determine if any restriction fragments were common to all three. The most suitable enzyme for comparison purposes was EcoRI, which had one site in pRCG4 and two sites in both pRCG9 and pRCG11. The three cosmids had an $11.5 \mathrm{~kb}$ EcoRI fragment in common. Cosmids pRCG9 and pRCG11 had the same restriction patterns and were regarded as being the same clone. Since the size of pRCG4 $(11.5 \mathrm{~kb})$ was too small for in vitro packaging during the construction of the gene bank, this cosmid must have been deleted in vivo prior to its purification. Stability studies on pRCG4 and pRCG9, using varying levels of antibiotic selection and repeated transformations of both plasmids, indicated that pRCG 9 was more stable than pRCG4. Consequently, pRCG9 was selected for further analysis. 

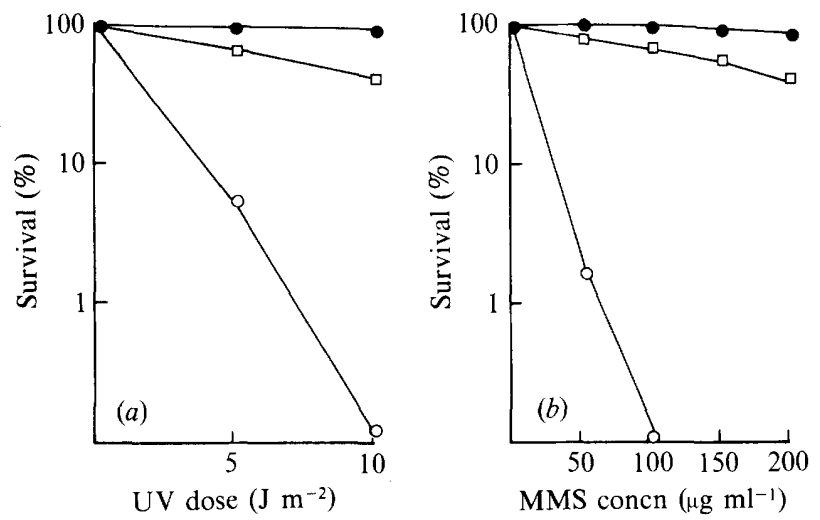

Fig. 2. UV (a) and MMS (b) survival analyses of E. coli S.17/pJC79 (O), S.17/pTM-2 (O) and S.17/pRCG9 ( $\square$ ). UV irradiations were done under gold light conditions to prevent enzymic photoreactivation.

\section{Quantitative effect of $p R C G 9$ on the UV and MMS survival of E. coli S.17}

Fig. 2(a) shows the effect of pRCG9 on the UV survival of the rec $A$ strain $E$. coli S.17. E. coli $\mathrm{S} .17 / \mathrm{pJC} 79$ was included as a negative control for $\mathrm{rec} A$ and S.17/pTM-2 was used as a positive $\mathrm{rec} A^{+}$control. A typical unshouldered survival curve for $\mathrm{S} .17 / \mathrm{pJC} 79$ was obtained, indicating the absence of complete repair capacity, whereas S.17/pTM-2 displayed a large shoulder over the dose range 0-10 J m ${ }^{-2}$, demonstrating the ability of the $r e c A^{+}$gene (from pTM-2) to increase the level of survival in the rec $A$ strain S.17. The effect of pRCG9 on the UV survival of S.17 was intermediate between the $\operatorname{rec} A$ mutant strain $(\mathrm{S} .17 / \mathrm{pJC} 79)$ and the repair-proficient strains (S.17/pTM-2). At $10 \mathrm{~J} \mathrm{~m}^{-2}$ the survival of S.17 was less that $1 \%$, whereas when this strain was transformed with pRCG9, UV survival increased to approximately $50 \%$.

To examine the effect of the recombinant cosmid pRCG9 on the MMS survival of a recA strain of E. coli, the responses of S.17/pJC79, S.17/pTM-2 and S.17/pRCG9 were determined by plating the cells onto increasing concentrations of MMS (Fig. 2b). S.17/pJC79 was extremely sensitive to the alkylating agent, with a survival of approximately $2 \%$ at $50 \mu \mathrm{g} \mathrm{MMS} \mathrm{ml}^{-1}$. The introduction of the $\operatorname{rec} A^{+}$genotype to $\mathrm{S} .17$ rendered the cells almost completely resistant. The presence of pRCG9 in S.17 enabled the cells to grow up to $200 \mu \mathrm{g} \mathrm{MMS} \mathrm{ml}{ }^{-1}$. At this concentration, S.17/pRCG9 had a $52 \%$ survival rate, compared to $93 \%$ survival for a wildtype strain. The $\operatorname{rec} A$ mutant showed no growth at this level of MMS. Above $50 \mu \mathrm{g} \mathrm{MMS} \mathrm{ml}{ }^{-1}$, the colonies appeared very small after $24 \mathrm{~h}$ growth.

\section{Effect of pRCG9 on filamentation in E. coli S.17}

Chromosomal damage caused by treatment of $E$. coli with a range of mutagens is alleviated by the induction of the SOS response (Witkin, 1976). This effect is controlled by a finely-tuned balance between the products of the $\operatorname{rec} A$ and $\operatorname{lex} A$ genes and is the major response to DNAdamaging treatment (Little \& Mount, 1982). Under normal growth conditions, the lexA protein represses expression of the SOS genes by binding to a specific recognition sequence at the operator, the SOS box (Little et al., 1981). The sfiA gene, which codes for cell division inhibition, is one of the genes under the control of lexA. After DNA damage or the perturbation of replication, sfiA is expressed, causing cell division arrest and the formation of long filaments. Filamentation is completely dependent on functional rec $A$-lexA circuitry. Since $E$. coli $\mathrm{S} .17$ has a deletion in the $\operatorname{rec} A$ gene, it has lost the ability to induce the SOS system, and thus filamentation, in response to DNA damage. The ability of pRCG9 to complement the recA mutation of $E$. coli S.17 and to promote the expression of filamentation was analysed with S.17/pJC79, S.17/pRCG9 and S.17/pTM-2. No microscopic evidence of filamentation in S.17/pJC79 was seen, whereas S.17/pRCG9 showed definite cellular filamentation (Fig. 3). S.17/pRCG9 showed no filamentation when non-irradiated cells were examined. The positive 

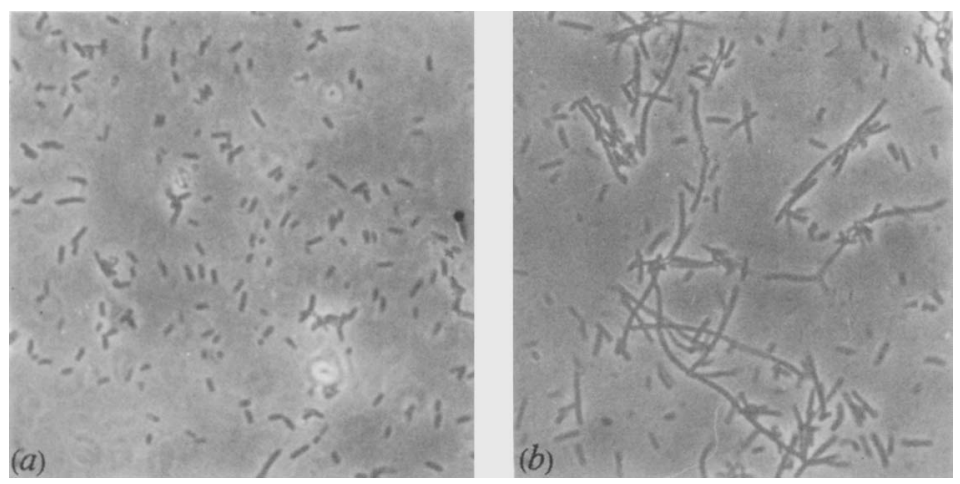

Fig. 3. Effects of UV irradiation $\left(5 \mathrm{~J} \mathrm{~m}^{-2}\right)$ on S.17/pJC79 (a) and S.17/pRCG9 (b). The presence of pRCG9 in S.17 enables the cells to form filaments in response to UV irradiation, implying that the cyanobacterial gene is capable of complementing the recA mutation of S.17 (see text).

control strain S.17/pTM-2 also showed cellular filamentation in response to UV irradiation, suggesting that a gene from pRCG9 was being expressed and synthesizing a protein capable of inducing filamentation either directly or indirectly. Although this effect could be explained by the existence of a pRCG9-associated gene which was involved in filamentation or the regulation of cell division in $G$. alpicola, neither UV nor mitomycin $\mathrm{C}$ induced filamentation in the cyanobacterium. It was therefore assumed that the filamentation effect was associated with the cosmid-linked rec $A$-complementing function.

\section{Subcloning the recA-complementing function from $p R C G 9$}

Digestion of pRCG9 with EcoRI yielded two fragments $(11.5 \mathrm{~kb}$ and $23.5 \mathrm{~kb})$. Since the $11.5 \mathrm{~kb}$ fragment was common to the original $\mathrm{rec} A$-complementing isolates from the gene bank, it was subcloned into pACYC184 and recA-complementing activity in S.17 and JC10289 was examined. Both EcoRI fragments from pRCG9 were successfully cloned into pACYC184. The transformants were screened for a chloramphenicol-sensitive, tetracycline-resistant phenotype and such clones were subsequently screened for increased UV survival characteristics. Eight clones showing higher UV resistance than S.17 alone were isolated and their plasmids were purified by $\mathrm{CsCl}$ centrifugation. These plasmids were retransformed into $\mathrm{JC} 10289$ and a UV survival analysis was performed to confirm their ability to increase the UV survival of $r e c A$ $E$. coli hosts. A low rate of plasmid instability was found among the JC10289/ pA-CYC184::pRCG9 transformants, and clones which had lost their recA-complementing phenotype had in vivo deletions in their plasmid DNA, as shown by alterations in the restriction patterns of the unstable plasmids. This loss of rec $A$-complementing ability accompanied by in vivo deletions in the plasmid DNA provided further evidence to assign a recA function to the cyanobacterial cosmid clone pRCG9.

\section{Restriction analysis of the recA-complementing pACYC184: :pRCG9 subclone}

Preliminary restriction analysis of the eight $r e c A$-complementing subclones demonstrated that they all contained the $11.5 \mathrm{~kb}$ EcoRI fragment of pRCG9. The pACYC184::pRCG9 hybrid plasmid selected for further analysis was designated pCL4. A restriction map of this plasmid is shown in Fig. 4.

An initial screening of the protein(s) encoded by the plasmid pCL4 was performed by transforming S.17 with pCL4, checking for a $\operatorname{rec} A$-complementing phenotype of the resulting transformants and preparing total proteins from an overnight culture for examination by SDSPAGE (Fig. 5). A major protein of approximately $39 \mathrm{kDa}$ was synthesized in the S.17/pCL4 strain, but was absent from the two control strains, S.17 and S.17/pACYC184. This protein, which is similar in molecular mass to the E. coli rec A protein (Sancar et al., 1980) and is coded for 


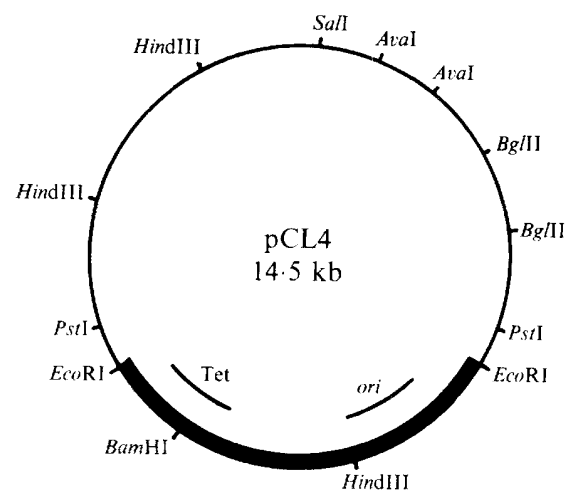

Fig. 4. Restriction map of the rec A-complementing plasmid pCL4.__- The vector pACYC184; - the EcoRI fragment subcloned from pRCG9.

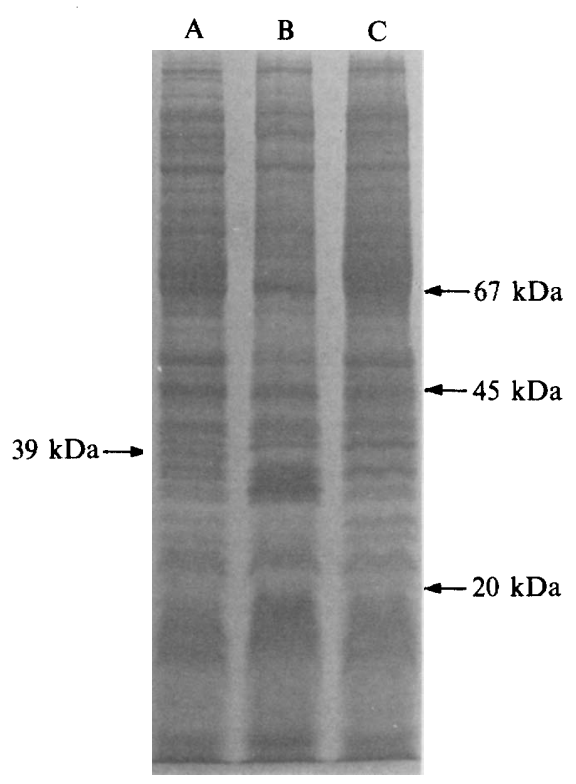

Fig. 5. SDS-PAGE analysis of total proteins synthesized in (A) S.17/pCL4, (B) S.17/pACYC184 and (C) S.17. Molecular mass standards were bovine serum albumin $(67 \mathrm{kDa})$, ovalbumin $(45 \mathrm{kDa})$ and trypsinogen $(24 \mathrm{kDa})$. The putative cyanobacterial ' $r e c A$ ' protein with an approximate molecular mass of $39 \mathrm{kDa}$ is indicated by the arrow in lane $\mathrm{A}$.

by the recombinant pCL4, may be the protein responsible for the increase in UV survival observed when this plasmid is present in the recA strain S.17.

The results of this study clearly show a strong conservation in the functional domains of the $r e c A$ proteins from two diverse organisms, $G$. alpicola and $E$. coli.

This work was financed in part by Euratom under its Biology-Health Protection Programme, contract no. BIOE-415-81-EIR.

\section{REFERENCES}

ALLEN, M. M. (1968). Simple conditions for the growth of unicellular blue-green algae on plates. Journal of Phycology 4, 1-4.
Birnboim, H. C. \& Doly, J. (1979). A rapid alkaline extraction procedure for screening recombinant plasmid DNA. Nucleic Acids Research 7, 1513-1523. 
HoHN, B. (1979). In vitro packaging of $\lambda$ and cosmid DNA. Methods in Enzymology 68, 299-309.

Jensen, T. E. \& Sicko, L. M. (1973). Fine structure of the cell wall of Gloeocapsa alpicola, a blue-green alga. Cytobiology 6, 439-446.

KUMAR, H. D. (1963). Effects of radiations on bluegreen algae: the production and characterization of a strain of Anacystis nidulans resistant to ultraviolet radiation. Annals of Botany 27, 723-733.

LitTle, J. W. \& Mount, D. W. (1982). The SOS regulatory system of Escherichia coli. Cell 29, 11-22.

Little, J. W., Mount, D. W. \& Yanis-Perron, C. R. (1981). Purified LexA protein is a repressor of the lexA and recA genes. Proceedings of the National Academy of Sciences of the United States of America 78, 4199-4203.

Maniatas, T., Fritsch, E. G. \& Sambrook, J. (1982). Molecular Cloning, a Laboratory Manual. Cold Spring Harbor, NY: Cold Spring Harbor Laboratory.

Marsden, H. S., Pollard, E. C., Ginoza, W. \& RANDALL, E. P. (1974). Involvement of rec $A$ and exr genes in the in vitro inhibition of the $\operatorname{rec} B C$ nuclease. Journal of Bacteriology 118, 465-470.

O'Brien, P. A. \& Houghton, J. A. (1982a). Photoreactivation and excision repair of $U V$ induced pyrimidine dimers in the unicellular cyanobacterium Gloeocapsa alpicola (Synechocystis PCC 6308). Photochemistry and Photobiology 35, 359-364.

O'Brien, P. A. \& Houghton, J. A. (1982b). UV induced DNA degradation in the cyanobacterium Synechocystis PCC 6308. Photochemistry and Photobiology 36, 417-422.

Rippka, R., Deruelles, J., Waterbury, J. B., Herdman, M. \& Stanier, R. Y. (1979). Generic assignments, strain histories and properties of pure cultures of cyanobacteria. Journal of General Microbiology 111, 1-61

Saito, N. \& Werbin, H. (1970). Purification of a bluegreen algal deoxyribonucleic acid photoreactivating enzyme. An enzyme requiring light as a physical cofactor to perform its catalytic function. Biochemistry 3, 2610-2620.

Sancar, A., Stachelek, C., Konigsberg, W. \& Rupp, W. D. (1980). Sequences of the $\operatorname{rec} A$ gene and protein. Proceedings of the National Academy of Sciences of the United States of America 77, 26112615.

Satta, G., Gudas, L. \& Pardee, A. B. (1979). Degradation of $E$. coli DNA : evidence for limitation in vivo by protein $\mathrm{X}$, the rec $A$ gene product. Molecular and General Genetics 168, 69-80.

Simon, R., Priefer, U. \& Puhler, A. (1983). A broad host range mobilization system for in vivo genetic engineering: transposon mutagenesis in Gram negative bacteria. Biotechnology 1, 784-791.

TANG, T. \& AsATO, Y. (1978). Ultraviolet light induction and photoreactivation of thymine dimers in the cyanobacterium Anacystis nidulans. Archives of Microbiology 118, 193-197.

Werbin, H. \& RUPerT, C. S. (1968). Presence of photoreactivating enzyme in blue-green algal cells. Photochemistry and Photobiology 7, 225-230.

Williams, E., LAMbert, J., O'Brien, P. \& Houghton, J. A. (1979). Evidence for dark repair of ultraviolet light damage in the blue-green alga Gloeocapsa alpicola. Photochemistry and Photobiology 29, 543547.

WITKIN, E. (1976). Ultraviolet mutagenesis and inducible DNA repair in Escherichia coli. Bacteriological Reviews 40, 869-907. 